\title{
Implementation Factors and Community Project Performance In Rwanda: A Case Of Water Aid Rwanda Project (Warp) In Gahanga Sector
}

\author{
Christella GIRIZINA RUGABIRA, Dr. Eugenia Nkechi Irechukwu \\ * Masters of Science in Project Management, Mount Kenya University \\ ** Project Supervisor, Mount Kenya University \\ DOI: 10.29322/IJSRP.11.11.2021.p11925 \\ http://dx.doi.org/10.29322/IJSRP.11.11.2021.p11925
}

\begin{abstract}
This paper explored the implementation factors and community project performance in Rwanda: A case study of Water Aid Rwanda Project (WARP) in Gahanga sector, Kicukiro District. The specific objectives were to establish the effects of project plan implementation, managerial support and manager's competence on community project performance of WARP in Gahanga sector in Kicukiro District. The study employed descriptive research design using quantitative and qualitative approaches. The study used questionnaire and interview guide to collect the data. Descriptive and inferential analysis such as frequencies, percentages, correlation and regression were used to present quantitative data in the form of tables using SPSS version 20 . The findings revealed that the majority of respondents agreed that there was well organized project work plan that is mutually understood by all employees before project implementation starts as shown by an agreement of $56 \%$ response, again $26 \%$ strongly agreed that project detailed work plan is discussed before project implementation. Besides, $70 \%$ and $26 \%$ agreed and strongly agreed that poor planning in projects affect projects completion time, cost and its quality, clarity on project work plan for staff members affect the projects implementation as shown by $55 \%$ and $42 \%$ who strongly agreed and agree. Regarding the effect of managerial support of WARP, the study found that lack of trust affects managerial support in implementation of WARP in Gahanga sector in Kicukiro district as pointed up by 53\% of respondents who agreed and $31 \%$ strongly agreed about it and finally $16 \%$ were neutral about that statement. Finally, the findings also revealed that there was a strong agreement of $74 \%$ that the project manager played a skilful role in facilitating the project implementation. The project manager of WARP in Gahanga sector possess soft skills which affect effective implementation of projects as agreed by $22 \%$. The study recommends that to effectively implement WARP, work plan must be clear to the project employees. Procedures should be in place to discuss the requirements of the project performance before starting the project to be implemented.
\end{abstract}

Keywords: Implementation, community, project and performance

\section{INTRODUCTION}

Worldwide, the achievement and manageability of any community project is highly dependent on its successful implementation which is intently attached to its planning exercise, managerial competence and managerial support (Gay, 2011) ${ }^{1}$. Projects flop because of lack of deficient planning, ordinarily on the grounds, they do not spell out the issues well or think about significant factors, for example, the necessities and perspectives on everybody associated with and influenced by the task. Successful planning gives subtleties and structure to project work plan and sets up an approach to proceed with the task after the close of financing, which means it is feasible (Gasik, 2016) ${ }^{2}$.

The success of the project has been the subject of much research and practice around the world. Almost all research focuses on the private sector, leaving a gap to date in the development of projects in the public sector (government-run projects). Most of the

\footnotetext{
${ }^{1}$ Gay, R. (2011). Considering sustainability factors in the development Project lifecycle. Issues in Educational Research, 136(8); 1326.

${ }^{2}$ Gasik, S. (2016). Project Management Development Practice and Perspectives, Paper presented at the $5^{\text {th }}$ International Scientific Conference on Project Management in the Baltic Countries in the University of Latvia, April $14-15$.
}

This publication is licensed under Creative Commons Attribution CC BY.

http://dx.doi.org/10.29322/IJSRP.11.11.2021.p11925

WWW.ijsrp.org 
world's nations place high priority on projects that have the objective to enhance economic and social development in countries where the managerial, economic and political environments differ drastically from those in developed countries (Harrwot,2011) ${ }^{3}$.

In Asia many projects, and indeed most construction projects, inevitably affect the communities in whose area they are carried out. Conversely, the opposite holds true that the benefitting communities also affect projects being rolled out in their areas. It is vital therefore to inform the residents in the affected areas as early as possible of the intent, purpose and benefits to the community of the project. Some projects cannot be started until after a public inquiry, environmental impact assessment, route survey or lengthy planning procedures (Fish, 2011). ${ }^{4}$

In the third world countries, the execution of many projects is combined with usual operational task in useful organizations with shortage of project management capacity (Liptrap,2019).5 The study done by Frimpong in 2003 on the aid deficit faced by government project in Ghana, he pointed out that it is clear that there are factors that depend on the money, the refusal, the funding, the directives of changes, design changes, design delays, misinformation, mismanagement of the contract, among many others, has proven to be the main source of protection.

According to Maylor (2015) ${ }^{6}$ many projects that have been planned properly have always performed in achieving their objectives while those with lack or poor planning have always failed at either the initial stages or failed to achieve the anticipated results. In Rwanda, some projects did not perform well and among the reasons of failure are poor planning, inappropriate objectives and targets, coordination of activities, mobilization of resources, and poor feasibility study (RDB, 2013) ${ }^{7}$. Therefore, it is against that gap the study was conducted on implementation factors and community project performance in Gahanga sector in Kicukiro District and took Water aid Rwanda Project (WARP) as a case study.

The general objective of this study was to assess the implementation factors and community project performance of WARP in Gahanga sector in Kicukiro District. The specific objectives were; To establish the effect of project plan implementation on the success of community project performance of WARP in Gahanga sector in Kicukiro District, to examine the effect of managerial support on the success of community project performance of WARP in Gahanga sector in Kicukiro District and to determine the effect of project manager's competence on community project performance of WARP in Gahanga sector in Kicukiro District.

\title{
$\underline{\text { 2.METHOD }}$
}

A descriptive survey design was used in this study to explore factors influencing successful implementation of community base projects. The aim of this study was to know the real and current information on the current situation, in order to reach a general conclusion about the results. Relations have been used to transform independent states based on change based. The research method was quantitative and qualitative. In this study, a simple regression was used to determine the value of the change in the function of the value of the other variable.

The population of the research was 6886 and a sample size of 142 was considered comprised in Gahanga sector Water Aid project, Kicukiro District-Rwanda. (Kicukiro Annual Report, 2019) ${ }^{8}$. The sample size was selected using census and simple random sampling techniques. The study drafted clear and specific questionnaires containing questions and interviews which were held with key informants.

The population involved in this study was staff from MINAGRI and beneficiaries from Bugesera district. The study was targeted these respondents owing to the fact that they are responsible for the management of WARP. The team of 4 field officers, 5 government officials, 2 cells executive, and 6875 beneficiaries were taken as total population.

Only the selected sample of members were served with the questionnaire. The study employed probability and non-probability sampling techniques to achieve reliability and validity of the research findings. Probability sampling encompasses simple random

\footnotetext{
${ }^{3}$ Harrwot, P. (2011). Project Success and Failure, and how can you improve your odds for success, Doctoral Dissertation. Translation, Stanley Epstein.

${ }^{4}$ Fish, H. (2011). Influence of stakeholder's involvement. Paper presented at the Conference on Human Development, Nashville, TN

${ }^{5}$ Liptrap, M. (2019). Stakeholder impact analysis in construction project management. Construction Management and Economics: 25(3), 277-287.
}

\author{
${ }^{6}$ Maylor, H., (2015). Project Management, 3rd edition. Harlow, Essex: Pearson Education Limited. \\ ${ }^{7}$ Rwanda development Board report, 2013 \\ ${ }^{8}$ Kicukiro annual report, 2019 \\ This publication is licensed under Creative Commons Attribution CC BY. \\ http://dx.doi.org/10.29322/IJSRP.11.11.2021.p11925
}

www.ijsrp.org 
ISSN 2250-3153

sampling, systematic sampling, stratified sampling, cluster random sampling and multistage (Kombo \& Tromp, 2006) ${ }^{9}$. Purposive sampling technique was used to select all respondents. The sample size of this study was 142 . The study sampled 2 government officers, 2 field officers, 2 cell executives and 136 beneficiaries. The researcher preferred to use the universal sampling technique to select respondents from the government officials and field officers because they are the ones who can provide useful information about implementation factors and community project performance of WARP.

Table 1:Table showing the sample distribution among the clusters

\begin{tabular}{lcc}
\hline Cluster & Target & Representative sample \\
\hline Government officials & 5 & 2 \\
WARP field officers & 4 & 2 \\
Cell executives & 2 & 2 \\
Beneficiaries & 6875 & 136 \\
Total & 6886 & 142 \\
\hline
\end{tabular}

Data collection methods was done from WARP in Gahanga sector in Kicukiro. Data was collected using a questionnaire with both open ended and closed ended questions structured to meet the objectives of the study. The sample size was 142 . After the necessary data being collected and entering into a computer, they were running through SPSS software, version 20 for analytical purpose.

Besides, the study also used interview guide. The researcher ensured that the same general areas of information were collected from each interviewee; this provides more focus than the conversational approach, but still allowed a degree of freedom and adaptability in getting information from the interviewee. Qualitative interview was given to government officials and field officers. The collection form clearly was focused on the point of interests. In order to construct the theoretical part, a number of books and online resources were consulted and referred to.

\section{RESULTS}

\subsection{The effect of effective project plan implementation of WARP}

In this research the study attempted to establish how effective planning affects successful project implementation in Gahanga sector.

Table 3.1: Project planning implementation

\begin{tabular}{|c|c|c|c|c|c|c|c|}
\hline Statement & $\begin{array}{l}\text { SD } \\
(\%)\end{array}$ & $\begin{array}{l}\mathrm{A} \\
(\%)\end{array}$ & $\begin{array}{l}\mathrm{N} \\
(\%)\end{array}$ & $\begin{array}{l}\text { SD } \\
(\%)\end{array}$ & $\begin{array}{l}\text { D } \\
(\%)\end{array}$ & Mean & $\begin{array}{c}\text { Std. } \\
\text { Deviation }\end{array}$ \\
\hline $\begin{array}{l}\text { The project detailed work plan was } \\
\text { discussed before project } \\
\text { implementation }\end{array}$ & $\begin{array}{c}35 \\
(26)\end{array}$ & $\begin{array}{c}74 \\
(56)\end{array}$ & $\begin{array}{c}21 \\
(16)\end{array}$ & $\begin{array}{c}3 \\
(2)\end{array}$ & $\begin{array}{c}0 \\
(0)\end{array}$ & 3.9366 & 0.34135 \\
\hline $\begin{array}{l}\text { Poor planning in projects affect } \\
\text { projects completion time, cost and } \\
\text { quality }\end{array}$ & $\begin{array}{c}93 \\
(70)\end{array}$ & $\begin{array}{c}34 \\
(26)\end{array}$ & $\begin{array}{c}5 \\
(3)\end{array}$ & $\begin{array}{c}1 \\
(1)\end{array}$ & $\begin{array}{c}0 \\
(0)\end{array}$ & 4.8380 & 0.43981 \\
\hline $\begin{array}{l}\text { Clarity on project work plan for } \\
\text { staff members affects the projects } \\
\text { implementation }\end{array}$ & $\begin{array}{c}56 \\
(42)\end{array}$ & $\begin{array}{c}74 \\
(55)\end{array}$ & $\begin{array}{c}2 \\
(2)\end{array}$ & $\begin{array}{c}0 \\
(0)\end{array}$ & $\begin{array}{c}1 \\
(1)\end{array}$ & 3.52282 & 0.55472 \\
\hline $\begin{array}{l}\text { WARP has always implemented } \\
\text { projects on time }\end{array}$ & $\begin{array}{c}33 \\
(29)\end{array}$ & $\begin{array}{c}86 \\
(65)\end{array}$ & $\begin{array}{c}7 \\
(5)\end{array}$ & $\begin{array}{c}3 \\
(2)\end{array}$ & $\begin{array}{c}4 \\
(6)\end{array}$ & 4.0493 & 0.21725 \\
\hline $\begin{array}{l}\text { WARP implements project work } \\
\text { plan effectively }\end{array}$ & $\begin{array}{c}3 \\
(2)\end{array}$ & $\begin{array}{r}119 \\
(89)\end{array}$ & $\begin{array}{l}10 \\
(7)\end{array}$ & $\begin{array}{c}1 \\
(1)\end{array}$ & $\begin{array}{c}0 \\
(0)\end{array}$ & 3.9789 & 0.27850 \\
\hline
\end{tabular}

\footnotetext{
${ }^{9}$ Kombo, D.K., and Tromp, L.A., (2006). Proposal and Thesis Writing. Paulines Publishers: Nairobi, Kenya This publication is licensed under Creative Commons Attribution CC BY. 
As indicated by Table 3.1, the majority of respondents (56\%) with a mean of 3.9366 with a standard deviation of 0.34 agreed that there was well organized project work plan that is mutually understood by all employees before project implementation starts. Besides, as $96 \%$ with a mean of 4.8380 with a standard deviation of 0.43981 agreed and strongly agreed that poor planning in projects affect projects completion time, cost and its quality, clarity on project work plan for staff members affect the projects implementation as agreed by $55 \%$ and strongly agreed by $42 \%$ with a mean of 3.52282 with a standard deviation of 0.5547 . Moreover, as agreed by $65 \%$ a mean of 4.0493 with a standard deviation of 0.21725 that WARP has always implemented on time. Lastly another group on the level how WARP implements work plan effectively, the majority of $89 \%$ agreed and $2 \%$ strongly agreed a mean of 3.9789 with a standard deviation of 0.27850 . They said that WARP plans are implemented effectively.

\subsection{The effect of managerial support on community project performance of WARP}

The second objective of the study was to determine the effect managerial support on community project performance. The following table gives us details:

Table 3.2: Managerial Support affects the WARP Community Project Performance

\begin{tabular}{|c|c|c|c|c|c|c|c|}
\hline Statements & $\begin{array}{l}\text { SA } \\
(\%) \\
\end{array}$ & $\begin{array}{l}\mathrm{A} \\
(\%) \\
\end{array}$ & $\begin{array}{l}\mathrm{N} \\
(\%)\end{array}$ & $\begin{array}{l}\text { D } \\
(\%)\end{array}$ & $\begin{array}{l}\text { SD } \\
(\%)\end{array}$ & Mean & $\begin{array}{c}\text { Std } \\
\text { Deviation }\end{array}$ \\
\hline $\begin{array}{l}\text { The trust between implementers and } \\
\text { managers affects project performance }\end{array}$ & $42(31)$ & $70(53)$ & $\begin{array}{c}21 \\
(16)\end{array}$ & $\begin{array}{c}0 \\
(0)\end{array}$ & $\begin{array}{c}0 \\
(0)\end{array}$ & 3.5775 & 0.71780 \\
\hline $\begin{array}{l}\text { Shared information is part of } \\
\text { managerial support that affects project } \\
\text { performance }\end{array}$ & $91(68)$ & $28(21)$ & $7(5)$ & $1(1)$ & $6(5)$ & 4.6408 & 0.72778 \\
\hline $\begin{array}{l}\text { Effective engagement of } \\
\text { implementers through managerial } \\
\text { support affects project performance }\end{array}$ & $63(47)$ & $56(41)$ & $7(5)$ & $7(5)$ & $0(0)$ & 3.9437 & 0.44202 \\
\hline
\end{tabular}

Table 3.2 above highlights the effect of managerial support on the performance of WARP in Gahanga sector. Regarding the first statement, the study found that trust between implementers and managers affects project performance as 53\% of respondents agreed with a mean of 3.5775 and standard deviation of 0.71780 . Besides, managerial support in implementation of WARP in Gahanga sector in Kicukiro district as pointed up by $68 \%$ of respondents with a mean of 4.6408 and standard deviation of 0.72778 who agreed. The majority of respondents (47\%) strongly agreed with a mean of 3.9437 and standard deviation of 0.44202 that effective engagement of implementers through managerial support affects project performance.

\subsection{The effect of project manager's competencies of WARP in Gahanga Sector}

For a project to be successful, the project manager must have the necessary project management skills, defined as planning, organizing, and monitoring all components of the project and encouraging all stakeholders to achieve the project goals efficiently and ahead of schedule, cost and project performance. In this research, the study attempted to establish how project manager's competencies affects successful implementation of WARP.

Table 3.3: Competence of WARP Managers in Gahanga Sector

\begin{tabular}{|c|c|c|c|c|c|c|c|}
\hline Statements & $\begin{array}{l}\mathrm{SA} \\
(\%)\end{array}$ & $\begin{array}{c}A \\
(\%)\end{array}$ & $\begin{array}{c}\mathrm{N} \\
(\%)\end{array}$ & $\begin{array}{c}\text { D } \\
(\%)\end{array}$ & $\begin{array}{l}\text { SD } \\
(\%)\end{array}$ & Mean & $\begin{array}{c}\text { Std } \\
\text { deviation }\end{array}$ \\
\hline $\begin{array}{l}\text { The project manager played a skillful role in } \\
\text { facilitating the project implementation }\end{array}$ & $\begin{array}{l}98 \\
(74)\end{array}$ & $\begin{array}{c}29 \\
(22)\end{array}$ & $\begin{array}{c}6 \\
(5)\end{array}$ & $\begin{array}{c}0 \\
(0)\end{array}$ & $\begin{array}{c}0 \\
(0)\end{array}$ & 3.7606 & 0.70389 \\
\hline
\end{tabular}

This publication is licensed under Creative Commons Attribution CC BY. 
The Project manager's technical capability is significant in project implementation

Educational qualifications of a project manager are important in project management.

Flexibility and alertness, human resource management, conflict management and positive attitude are qualities of project manager
32

81

(61)

82

43

10

(8)

2

(2)

8

(5)

3.5845

0.71700

197

\begin{tabular}{ccccccc}
108 & 11 & 5 & 5 & 4 & 3.8112 & 0.69584 \\
$(81)$ & $(8)$ & $(4)$ & $(4)$ & $(3)$ & & \\
& & & & & & \\
\hline
\end{tabular}

From the table above, it indicates that there was a strong agreement of $74 \%$ that the project manager played a skillful role in facilitating the project implementation. The project manager of WARP in Gahanga sector possess soft skills which affect effective implementation of projects as agreed by $74 \%$ with a mean of 3.7606 with 0.70389 standard deviation. Moreover, on the point of project managers' technical capability which is significant in project management, the majority $94 \%$ respondents agreed with a mean of 3.5845 and standard deviation of 0.717 Besides, educational qualifications of a project manager are also important in implementation of a project management as shown by $62 \%$ response percentage of respondents who strongly agreed with a mean of 4.2606 and standard deviation of 1.30835. Further, flexibility and alertness, human resource management, conflict management and positive attitude are qualities that the project manager possesses as strongly agreed by the majority of respondents (81\%) and $8 \%$ agreed, $4 \%$ was undecided, $4 \%$ strongly disagreed and 3\% disagreed with a mean of 3.8112 and a standard deviation of 0.69584 .

\section{DISCUSSION}

\subsection{Project planning implementation}

From the findings of this study, good planning is an important part of a project that reflects the performance and success. It is an ongoing project. In addition, project planning plays an important role in helping to manage partners, sponsors, teams and project managers through other phases of the project. Planning is necessary to determine desired goals, reduce impact, avoid delays and finally deliver the best products, services or solutions. Without proper planning, the performance of the project will suffer absolutely.

The planning phase involves creating a project plan, requesting deliverables and drawing up a project schedule. A plan is in place to help the team manage the implementation and completion of each phase of the project. Programmes developed in this category help manage time, cost, quality, change, risk and related issues. They also help monitor employees and external contractors to ensure that the project is completed on time, on budget and on schedule.

\subsection{The effect of managerial support on community project performance of WARP}

From the findings they study reveal that managerial support affects the community project performance of WARP through the trust between implementers and managers which affects project performance and also through sharing information that affect in project performance. Besides, as highlighted by the study managerial support of WARP also affects the community project performance through effective engagement. Normally all the members of the project team are responsible. The project teams share partial and permanent contributions and for the benefit of the WARP. The target is also the potential of the team and the team's strength of WARP. Study research carried out by Therry \& Deguire (2017) ${ }^{10}$ stated that management support is widely cited factors ranked at the highest level for projects across the industries. It plays an insignificant role in project outcomes. The success or failure of projects in organizations depends on the intensity of support from the top management.

\subsection{The WARP Project Manager's Competencies in Gahanga Sector}

\footnotetext{
${ }^{10}$ Therry, M. and Deguire, M. (2017). Recent Developments in Projects-Based Organizations. International Journal of Project Management, 14(12), 779- 786

This publication is licensed under Creative Commons Attribution CC BY.

http://dx.doi.org/10.29322/IJSRP.11.11.2021.p11925

WWW.ijsrp.org
} 
The WARP project manager is a person with overall responsibility for the successful start-up, planning, operation, control, monitoring and closure of the project. He has the skills to ask inbound questions, understand unspoken ideas and resolve conflicts, and general management skills. As indicated the results adequate technical skills can be acquired relatively quickly and that it is important for the project manager to be a professional and objectively-minded person - such a person is able to rise above the details as is the project manager of WARP.

Flexibility and alertness, human resource management, conflict management and positive attitude affect WARP project manager effective implementation of projects. Some qualities all project managers should have includes being democratic, influential, communicative, decision maker, problem solver and knowledgeable as well.

This study concurs with the findings of Liptrap (2019) ${ }^{11}$ when he analyzed project manager Competency: A tool for project success in Malesia. The study was aimed to explore how leadership competency is important for the project success. For the purpose data was collected from the published articles from well-known databases. It was found that leadership competency has positive impact on the project success which was previously neglected due to some unknown reasons. The study also found that project managers competencies are a universal topic and has been an effective source for organizational success yet in project management it is evolving. Finally, as per prior studies, it was concluded that project leadership competencies are similar to competencies of leadership in general management.

\section{CONCLUSION}

The findings of this study reveal effective planning affects effective implementation of WARP in Gahanga sector. The study concludes that WARP is a well-organized project work plan that is mutually understood by all team work before project implementation. In addition, project detailed work plan is discussed before project implementation, effective planning in projects affect projects completion time, cost and its quality, clarity on project work plan and project performance in particular. Besides, the study also reveals that managerial support of WARP affects successful implementation of project performance at Gahanga sector. Finally, the study also concludes that project manager soft skills more affect the success of the project performance. Thus, the project manager of WARP has had technical and academic qualifications which would help the project to be achieved.

\section{RECOMMENDATIONS}

Based on the findings, the following recommendations were suggested:

i. Planning phase of formulating projects is a basic stage for its success. So, the study recommends that there should be clear and specific schedule (plan) in order to improve the projects quality performance.

ii. The study also recommends that the management and team cohesion and involvement should be enhanced to improve the plan (schedule) effectiveness of projects.

iii. The study further recommends that all projects should have project managers as they affect implementation of project performance, it also recommends that besides technical and education background, the project manager must also have soft skills for successful project implementation

\section{REFERENCES}

Fish, H. (2011). Influence of stakeholder's involvement. Paper presented at the Conference on Human Development, Nashville, TN

Gay, R. (2011). Considering sustainability factors in the development Project lifecycle. Issues in Educational Research, 136(8); 13-26.

${ }^{11}$ Liptrap, M. (2019). Stakeholder impact analysis in construction project management. Construction Management and Economics: 25(3), 277-287.

This publication is licensed under Creative Commons Attribution CC BY.

http://dx.doi.org/10.29322/IJSRP.11.11.2021.p11925

WWW.ijsrp.org 
Gasik, S. (2016). Project Management Development Practice and Perspectives, Paper presented at the $5^{\text {th }}$ International Scientific Conference on Project Management in the Baltic Countries in the University of Latvia, April $14-15$.

Harrwot, P. (2011). Project Success and Failure, and how can you improve your odds for success, Doctoral Dissertation. Translation, Stanley Epstein.

Liptrap, M. (2019). Stakeholder impact analysis in construction project management. Construction Management and Economics: 25(3), 277-287.

Maylor, H., (2015). Project Management, 3rd edition. Harlow, Essex: Pearson Education Limited.

Kicukiro annual report, 2019

Kombo, D.K., and Tromp, L.A., (2006). Proposal and Thesis Writing. Paulines Publishers: Nairobi, Kenya

Rwanda development Board report, 2013

Therry, M. and Deguire, M. (2017). Recent Developments in Projects-Based Organizations. International Journal of Project Management, 14(12), 779- 786

\section{ACKNOWLEDGEMENT}

Firstly, I am thankful to God Almighty for my creation and being on my side towards my study accomplishment.

I am principally indebted to Mount Kenya University staff, particularly to my supervisor Dr. Eugenia Nkechi Irechukwu for her patience, motivation and for her continuous support.

I am grateful to my husband Jules Mukulira, my late father Aciel Nzamwita Rugabira, my mother Julienne Mukandekezi, my brother and sisters for their love, their tenderness, their attention, their encouragement, their steadfast support and sacrifices they endured during my studies.

I would like to thank the management, staff of WRAP for allowing me the opportunity to make research in their project. May the Lord bless you abundantly.

All of you have, in one way or another, contributed to my moral, financial and academic success. 